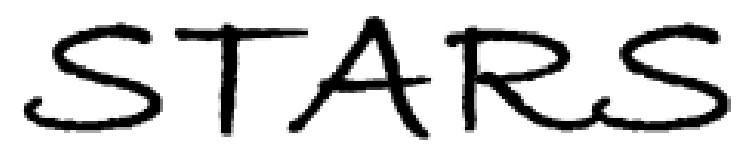

University of Central Florida

STARS

Faculty Bibliography 2000s

Faculty Bibliography

$1-1-2007$

\title{
Dune vegetation fertilization by nesting sea turtles
}

Laura B. Hannan

University of Central Florida

James D. Roth

University of Central Florida

Llewellyn M. Ehrhart

University of Central Florida

John F. Weishampel

University of Central Florida

Find similar works at: https://stars.library.ucf.edu/facultybib2000

University of Central Florida Libraries http://library.ucf.edu

This Article is brought to you for free and open access by the Faculty Bibliography at STARS. It has been accepted for inclusion in Faculty Bibliography 2000s by an authorized administrator of STARS. For more information, please contactSTARS@ucf.edu.

\section{Recommended Citation}

Hannan, Laura B.; Roth, James D.; Ehrhart, Llewellyn M.; and Weishampel, John F., "Dune vegetation fertilization by nesting sea turtles" (2007). Faculty Bibliography 2000s. 7204.

https://stars.library.ucf.edu/facultybib2000/7204

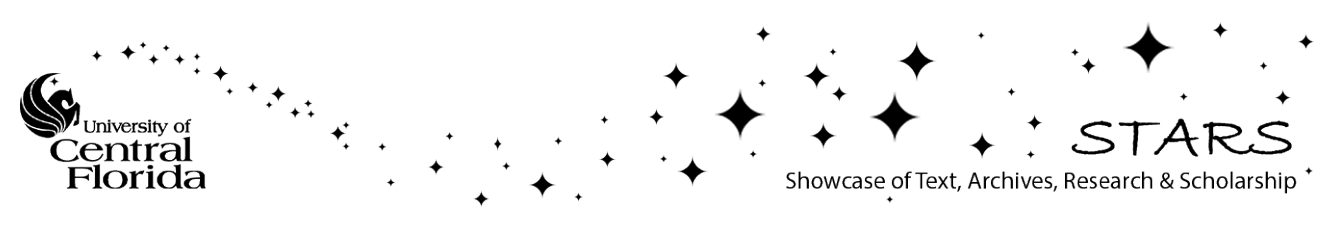




\title{
DUNE VEGETATION FERTILIZATION BY NESTING SEA TURTLES
}

\author{
Laura B. Hannan, James D. Roth, Llewellyn M. Ehrhart, and John F. Weishampel ${ }^{1}$ \\ Department of Biology, University of Central Florida, Orlando, Florida 32816 USA
}

\begin{abstract}
Sea turtle nesting presents a potential pathway to subsidize nutrient-poor dune ecosystems, which provide the nesting habitat for sea turtles. To assess whether this positive feedback between dune plants and turtle nests exists, we measured $\mathrm{N}$ concentration and $\delta^{15} \mathrm{~N}$ values in dune soils, leaves from a common dune plant (sea oats [Uniola paniculata]), and addled eggs of loggerhead (Caretta caretta) and green turtles (Chelonia mydas) across a nesting gradient (200-1050 nests $/ \mathrm{km}$ ) along a $40.5-\mathrm{km}$ stretch of beach in east central Florida, USA. The $\delta^{15} \mathrm{~N}$ levels were higher in loggerhead than green turtle eggs, denoting the higher trophic level of loggerhead turtles. Soil $\mathrm{N}$ concentration and $\delta^{15} \mathrm{~N}$ values were both positively correlated to turtle nest density. Sea oat leaf tissue $\delta^{15} \mathrm{~N}$ was also positively correlated to nest density, indicating an increased use of augmented marine-based nutrient sources. Foliar $\mathrm{N}$ concentration was correlated with $\delta^{15} \mathrm{~N}$, suggesting that increased nutrient availability from this biogenic vector may enhance the vigor of dune vegetation, promoting dune stabilization and preserving sea turtle nesting habitat.
\end{abstract}

Key words: allochthonous input, barrier island ecology; Caretta caretta; Chelonia mydas; facilitation; green turtle; loggerhead; nitrogen deposition; nutrient transport; sea oats; stable isotopes; Uniola paniculata.

\section{INTRODUCTION}

Dune ecosystems are often nutrient-poor, harsh environments (Kachi and Hirose 1983, Hayden et al. 1991, Hesp 1991). Excessively drained, sandy soil leads to intensive leaching, and thus the system often depends on allochthonous (originating in another ecosystem) nutrient inputs from meteorologic (Art et al. 1974) or marine sources (Heatwole 1971, Allaway and Ashford 1984). Sea turtles, through nesting, annually transport substantial amounts of nutrients and energy to the beaches of east central Florida (Bouchard and Bjorndal 2000), originating from Caribbean and Gulf of Mexico foraging grounds hundreds to thousands of kilometers away. Sea turtles may stabilize these dune systems, which provide nesting habitat, by fertilizing dune plants whose roots reduce beach erosion.

However, the deposition of nutrients does not necessarily demonstrate that they are assimilated into the terrestrial ecosystem or are critical for system functioning. Here, we determined the extent to which marine-derived nitrogen $(\mathrm{N})$ from sea turtle nesting is found in the soil and absorbed by the coastal vegetation by using stable isotope analysis. Marine nutrient sources

Manuscript received 14 April 2006; revised 13 October 2006; accepted 27 October 2006. Corresponding Editor: J. J. Stachowicz.

${ }^{1}$ Corresponding author. E-mail: jweisham@mail.ucf.edu are usually enriched in ${ }^{15} \mathrm{~N}$ compared to terrestrial sources (Schoeninger et al. 1982), so differential use of these sources should be reflected in the stable $\mathrm{N}$ isotope ratios of plant tissues. Our objective was to determine whether sea turtles function as biogeochemical interfaces between marine and terrestrial systems, as has been found with other animals, such as river otters (BenDavid et al. 1998a), salmon (Ben-David et al. 1998b, Bartz and Naiman 2005), sea lions (Fariña et al. 2003), and seabirds (Anderson and Polis 1999, Sánchez-Piñero and Polis 2000, Ellis et al. 2006). Beyond functioning as a nutrient vector between ecosystems, sea turtles may help maintain their own nesting environment by providing nutrient subsidies to dune vegetation that plays a role in dune stabilization.

\section{Methods}

The study area is located along a $40.5-\mathrm{km}$ stretch of beach on the east central coast of Florida that extends northward from Sebastian Inlet to the Patrick Air Force Base; the southern $21.0 \mathrm{~km}$ is less developed and incorporates the Archie Carr National Wildlife Refuge. These beaches provide nesting habitat for the second largest population of loggerheads (Caretta caretta) in the world, the largest population of green turtles (Chelonia mydas) in the continental United States, and the occasional leatherback (Dermochelys coriacea) (Ehr- 


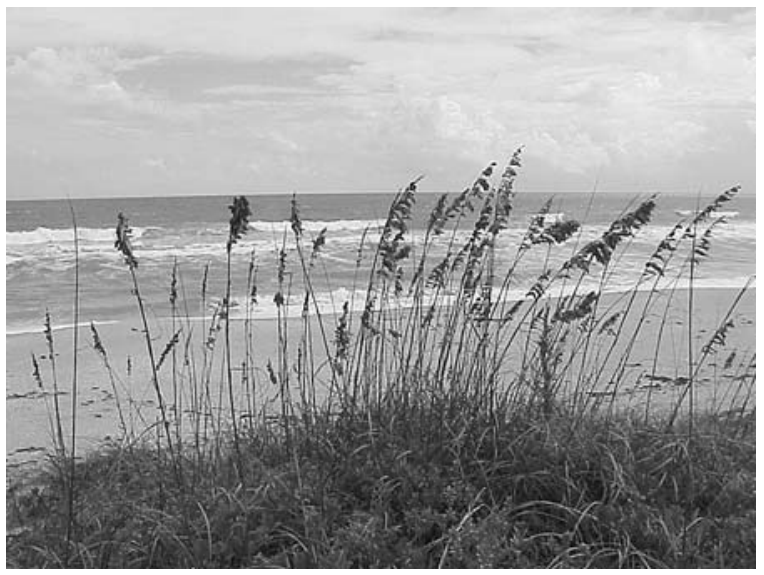

Plate 1. Dune with sea oats (Uniola paniculata) overlooking the beach at the Archie Carr National Wildlife Refuge, Florida, USA. Photo credit: L. Hannan.

hart and Raymond 1983; see also Archie Carr National Wildlife Refuge web site) $)^{2}$. The distribution of nests along the beach is not uniform, but resembles a gradient (Weishampel et al. 2003). Over the 15 -year period from 1989 through 2003, the southern half of the study area had 2.3 times the number of loggerhead nests (649 nests $\left.\mathrm{km}^{-1}\right)$ and 3.8 times the number of green turtle nests $\left(34.7\right.$ nests $\left.\mathrm{km}^{-1}\right)$ as the northern half. Though the annual number of nests for each species fluctuates and loggerhead nesting has been occurring earlier each season (Weishampel et al. 2004), the general spatial patterns of nest distribution have been very consistent inter- and intra-annually (Weishampel et al. 2003, 2006).

Loggerhead and green turtle clutches over a recent 5year period averaged 114 eggs and 128 eggs, respectively (D. Bagley, personal communication), but loggerhead nests vastly outnumber green turtle nests at this site ( $>20: 1$ from 1989 to 2003). However, green turtles, on average, nest $\sim 5 \mathrm{~m}$ closer to the base of the foredune than loggerheads do (Witherington 1986). Nest chamber depth may also affect accessibility of nutrients to plant roots; loggerheads typically bury their eggs $35 \mathrm{~cm}$ below the surface (Carthy et al. 2003), while the mean depth of a green turtle clutch is $58 \mathrm{~cm}$ (Johnson 1994). Given oviposition preferences in relation to the foredune, it is unclear which turtle species may directly contribute more nutrients. However, among monitored nests, plant roots penetrated a higher percentage of loggerhead eggs $(0.30 \%)$ than green turtle eggs $(0.13 \%$; Osegovic 2001$)$.

To assess the contribution of nutrients from marine turtle nests to dune vegetation, we determined the overall nitrogen concentration and isotopic signatures $\left(\delta^{15} \mathrm{~N}\right)$ in samples of turtle eggs, soils, and sea oats (Uniola paniculata). This perennial grass is typically the dominant foredune plant and is considered to be a

${ }^{2}\langle$ http://www.fws.gov/archiecarr/ pioneer as well as a climax species (see Plate 1). Sea oats have an association with $\mathrm{N}$-fixing bacteria (Dalton et al. 2004), possibly contributing to its facilitative role in the beachside community, which is considered economically important for building and maintaining dunes (Snyder and Boss 2002, Miller et al. 2003). Its root mass is primarily concentrated laterally in the upper $30 \mathrm{~cm}$ of the soil, closer to the depths of loggerhead nests, but a tap root typically extends deeper, toward the depth of green turtle nests, to $\sim 0.9 \mathrm{~m}$ above the water table (Hester and Mendelssohn 1989).

We collected addled eggs of loggerheads and green turtles across the gradient of nest densities during the nesting season (May through September) in 2002. Addled eggs are those that contain yolk but no visible sign of development. On these beaches, typically $14 \%$ of the eggs in a nest are addled for each species (Osegovic 2001). Nests were marked the morning after oviposition by researchers monitoring sea turtle nesting activity (Weishampel et al. 2003). After 70 days of incubation (hatchlings on these beaches typically emerge at $\sim 50$ days), 20 loggerhead and 16 green turtle nests located along the $40.5-\mathrm{km}$ stretch of shoreline were excavated and one unhatched egg was retrieved from each nest for isotopic analysis.

Samples of the sand-dominated soil were collected from the foredune ( $1 \mathrm{~m}$ from the base of the dune) at 15 sites situated $1-3.25 \mathrm{~km}$ apart along the $40.5-\mathrm{km}$ beach in April 2003. At each site, a cylindrical soil core (1 m deep $\times 0.03 \mathrm{~m}$ in diameter) was acquired. Depths were mixed for analysis. Sections of sea oat leaf blades were clipped from different individual plants in August 2002 $(N=13)$ and April $2003(N=21)$ prior to the onset of the 2003 nesting season (Weishampel et al. 2004). Sea oat tissues were collected from the foredune from several ocean side parks and near other beach access points representing $160.5-\mathrm{km}$ beach segments of different nesting densities. Specific plants were selected without consideration of distance to specific sea turtle nests or the soil core samples.

Samples were kept frozen prior to analysis. Plant samples were rinsed with tap water to remove excess soil or debris. Shells were removed from eggs. All samples were freeze-dried for 48 hours before being homogenized with mortar and pestle. Lipids were removed from eggs using a Soxhlet apparatus (Fisher Scientific, Waltham, Massachusetts, USA) with petroleum ether solvent for $12 \mathrm{~h}$. N concentration and $\delta^{15} \mathrm{~N}$ of subsamples $(1 \mathrm{mg}$ for eggs, $4 \mathrm{mg}$ for plants, and $40 \mathrm{mg}$ for soils) were measured using a continuous flow isotope ratio mass spectrometer in the National Center for Forensic Science at the University of Central Florida (Orlando, Florida, USA). $\mathrm{N}$ concentration is expressed as a percentage of dry mass of the soil and tissue samples and stable isotope ratios are expressed as parts per thousand (\%o) relative to atmospheric $\mathrm{N}: \delta^{15} \mathrm{~N}=\left(R_{\mathrm{smp}}-\right.$ 

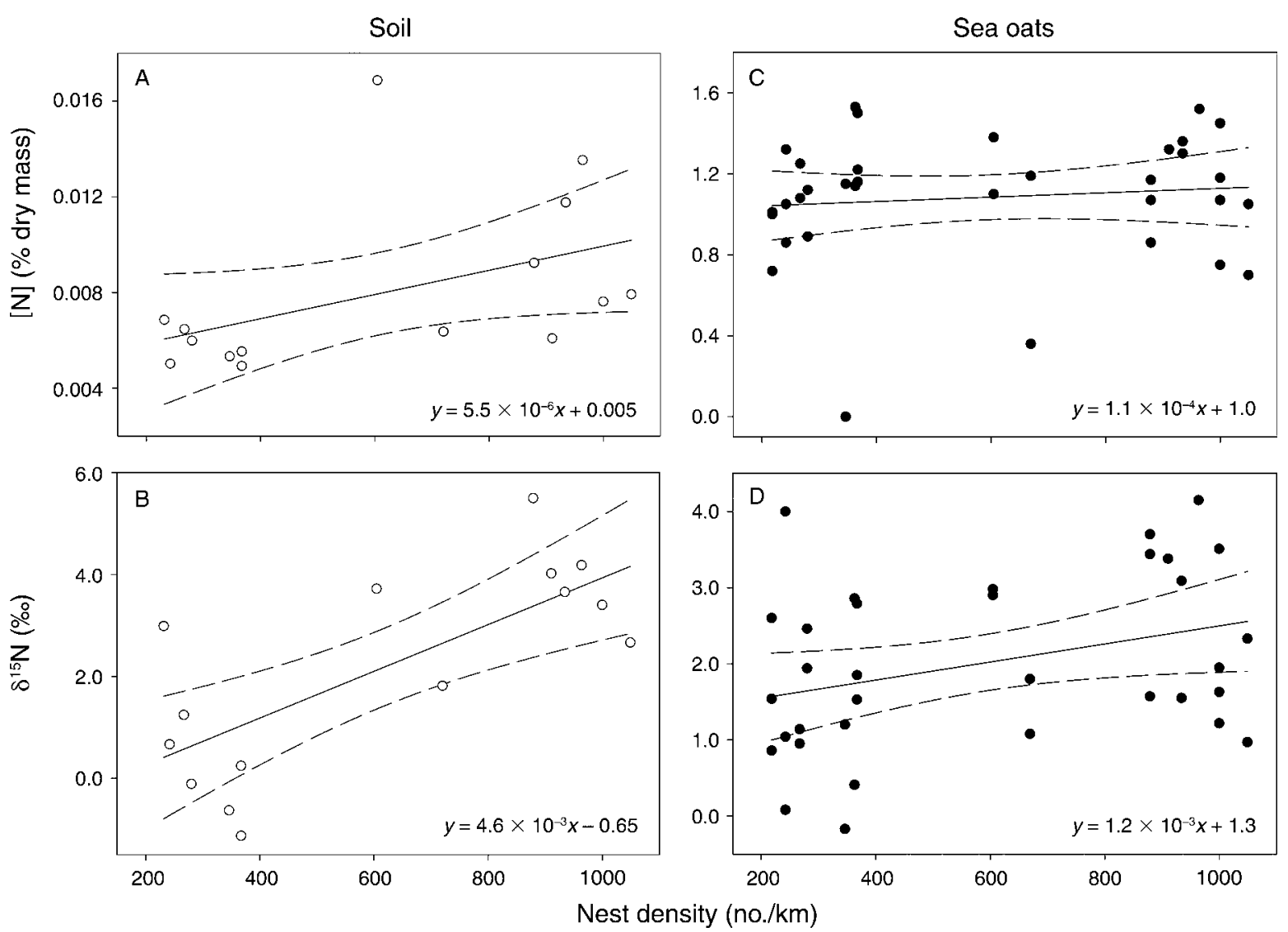

FIG. 1. Mean five-year (1998-2002) nest density for loggerhead and green turtles within 0.5-km beach segments in relation to (A) $\mathrm{N}$ concentration and (B) $\delta^{15} \mathrm{~N}$ in soil cores (open circles); and to (C) $\mathrm{N}$ concentration and (D) $\delta^{15} \mathrm{~N}$ in sea oat leaf tissue (solid circles). $\mathrm{N}$ concentration is expressed as a percentage of dry mass of the soil and tissue samples, and stable isotope ratios are expressed as parts per thousand (\%) relative to atmospheric N. The relationships shown were based on untransformed values. Dashed lines represent $95 \%$ confidence envelopes.

$\left.R_{\text {std }}\right) / R_{\text {std }}$, where $R={ }^{15} \mathrm{~N} /{ }^{14} \mathrm{~N}$ (Lajtha and Marshall 1994).

After evaluating the data for normality and homoscedasticity assumptions, $\mathrm{N}$ concentration values from soil and tissue (both addled eggs and sea oats) were logarithmically and reflect-logarithmically transformed, respectively. The latter transformation technique is appropriate when data have a negative skewness (Tabachnick and Fidell 2007). We conducted one-way ANOVA analyses on $\delta^{15} \mathrm{~N}$ and transformed $\mathrm{N}$-concentration values to assess species-level differences in the addled-egg tissues and differences in the sea oat tissues collected in August 2002 and April 2003. Linearregression analyses were run to compare turtle nest densities (loggerhead and green turtle combined) within each $0.5-\mathrm{km}$ beach segment and corresponding soil and sea oat $\delta^{15} \mathrm{~N}$ and transformed $\mathrm{N}$ concentration values. Because nest densities, especially those of green turtles, often fluctuate from year to year (Weishampel et al. 2003, 2006) and because sea oats are a perennial grass, we averaged nest densities over the five-year period that preceded sampling (1998-2002).

\section{RESUlts}

The $\delta^{15} \mathrm{~N}$ values of green turtle $(6.0 \%$ o $\pm 0.3 \%$; mean $\pm \mathrm{SE})$ and loggerhead $(10.6 \%$ $\pm 0.6 \%)$ eggs differed significantly $\left(F_{1,34}=36.0, P<0.001\right)$. This difference was expected, as the largely carnivorous loggerhead turtles occupy a higher trophic position than the largely herbivorous green turtles (Godley et al. 1998). Soil samples increased in $\mathrm{N}$ concentration $\left(F_{1,13}=5.7, P=\right.$ $\left.0.03, R^{2}=0.31\right)$ and $\delta^{15} \mathrm{~N}\left(F_{1,13}=15.1, P=0.002, R^{2}=\right.$ $0.54)$ with higher nest density (Fig. 1A, B). Soil $N$ concentration and $\delta^{15} \mathrm{~N}$ were significantly correlated (Fig. 2A; Pearson $r=0.64, P=0.01$ ). The sea oats samples from August 2002 and April 2003 did not differ in N concentration $\left(F_{1,32}=2.65, P=0.20\right)$ or $\delta^{15} \mathrm{~N}\left(F_{1,32}\right.$ $=0.11, P=0.74)$; thus, the samples from the two collection periods were combined. Sea oat N concentration was two orders of magnitude higher than soil $\mathrm{N}$ concentration but was unrelated to nest density (Fig. 1C; 

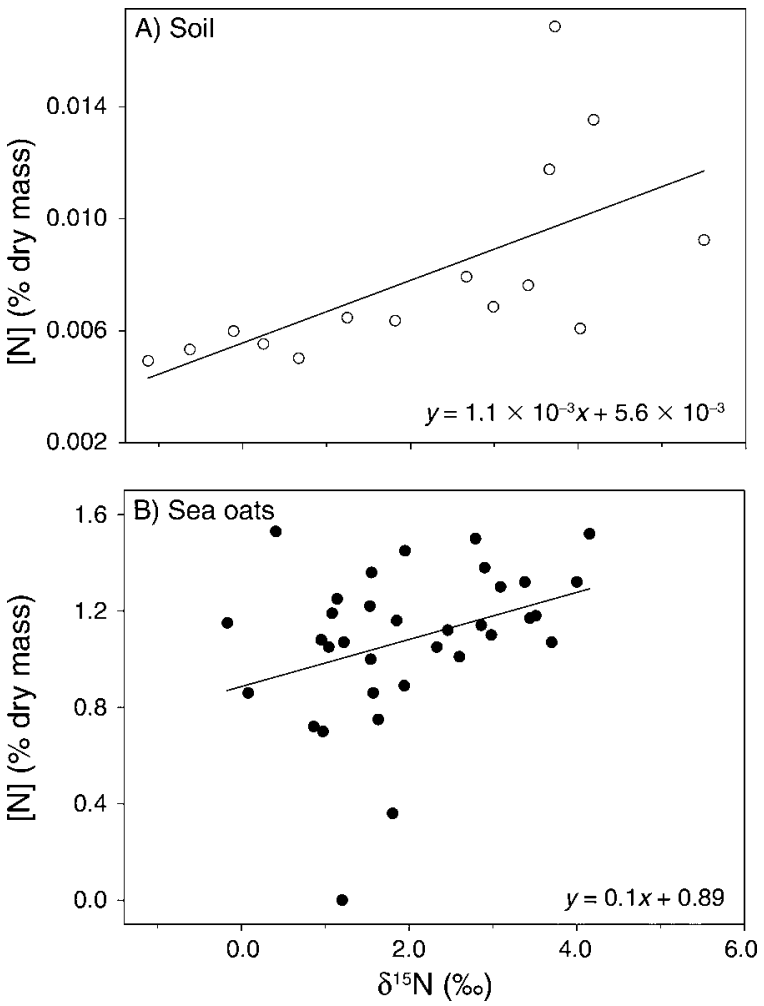

FIG. 2. Relationships between $\delta^{15} \mathrm{~N}$ and $\mathrm{N}$ concentration in (A) dune soil and (B) sea oats foliar tissue.

$\left.F_{1,32}=0.39, P=0.54, R^{2}=0.01\right)$. Foliar $\delta^{15} \mathrm{~N}$, however, was positively related to mean nest density $\left(F_{1,32}=4.1, P\right.$ $=0.05, R^{2}=0.11$; Fig. 1D), and foliar $\mathrm{N}$ concentration and $\delta^{15} \mathrm{~N}$ were significantly correlated (Fig. $2 \mathrm{~B} ; r=0.35$, $P=0.04)$ in sea oats. In a related analysis (Plog 2004), sea oat $\delta^{15} \mathrm{~N}$ levels were found to be significantly higher (ANOVA, $F_{1,34}=4.6, P=0.04$ ) in the higher nest density, southern half of the study area than the lower nest density, northern half.

\section{Discussion}

Enriched $\delta^{15} \mathrm{~N}$ levels in soil and foliar tissue in the high nest region indicate that $\mathrm{N}$ from marine sources, most likely transported by sea turtles to these beaches, was assimilated by the dune vegetation. The positive relationship between $\delta^{15} \mathrm{~N}$ signatures in sea oats and nest density supports visible evidence that sea turtle nests at the Archie Carr National Wildlife Refuge are commonly invaded by roots from the dune vegetation; Bouchard and Bjorndahl (2000) found 23\% of examined loggerhead nests were invaded by plant roots growing around and often penetrating shells. Other studies have recorded vegetation predation on fresh- and brackish-water turtle eggs. Roots from beachgrass (Ammophila breviligulata) sometimes surround diamondback terrapin (Malaclemys terrapin) eggs to form massive clumps (Lazell and Auger
1981) and absorb nutrients through the shell (Stegmann et al. 1988). Roots from beardgrass (Andropogon sp.) have been documented to penetrate yellow-bellied turtle (Chrysemys scripta) eggs (Turkowski 1972).

Although $\mathrm{N}$ concentration in sea oats was not correlated with turtle nest density, the significant correlation of $\mathrm{N}$ concentration with $\delta^{15} \mathrm{~N}$ suggests that $\mathrm{N}$ availability on the dunes is limiting and dune plants exploit higher $\mathrm{N}$ levels due to sea turtle nesting. The spatial scale of our nest-density data may have been too coarse to capture fine-scale heterogeneity in nutrient availability experienced by individual plants. But the elevated $\mathrm{N}$ concentration in plants that were subsidized by the marine-based nutrients in sea turtle nests may promote growth (Wagner 1964, Hester and Mendelssohn 1990, Day 1996) that contributes to the maintenance and stabilization of the coastal dunes. Although other marine-derived $\mathrm{N}$ sources for these dunes exist, e.g., from seaweed (Sargassum sp.) or carrion (see Plog 2004), compared to turtle eggs, these contributions are minimal (Bouchard and Bjorndal 2000). Furthermore, the distribution of these other sources is not concentrated in the southern end of the study area (L. Ehrhart, personal observation).

Sea oats from dunes with lower nest densities may be able to compensate for the associated reduced soil $\mathrm{N}$ concentration in several ways. Under lower soil $\mathrm{N}$ concentration, there may be reduced shoot: root growth (Stevenson and Day 1996) to maintain the tissue $\mathrm{N}$ concentration, enhanced mycorrhizal (Sylvia 1986) associations to increase $\mathrm{N}$ uptake, or the symbiotic relationship with $\mathrm{N}$-fixing bacteria may be magnified (Dalton et al. 2004). Even with the potential capacity to fix atmospheric $\mathrm{N}$, the greater accessibility of marinederived $\mathrm{N}$ to sea oats in the higher density nesting areas was apparent by the higher $\delta^{15} \mathrm{~N}$ values. Using existing soil $\mathrm{N}$ may be more energy efficient than fixing atmospheric $\mathrm{N}$ because symbiotic bacteria require carbohydrates from the plant to generate ammonia $\left(\mathrm{NH}_{4}{ }^{+}\right.$), which is absorbed by the host (van Berkum and Bohlool 1980).

In general, the overall $\delta^{15} \mathrm{~N}$ levels found in sea oats, even in the high density nesting areas, were relatively low compared to most (e.g., Ben-David et al. 1998a, Wainright et al. 1998, Anderson and Polis 1999, Fariña et al. 2003, Ellis et al. 2006) but not all (e.g., Ben-David et al. 1998b, Bartz and Naiman 2005) examples of fertilization from animal transport of marine nutrients. As indicated by Peterson and Fry (1987), N-fixing plants have lower $\delta^{15} \mathrm{~N}$ levels than non-fixers; for example, alder (Alnus sp.) found near river otter latrines did not show enriched $\delta^{15} \mathrm{~N}$ levels (Ben-David et al. 1998a). Other factors that may contribute to the reduced $\delta^{15} \mathrm{~N}$ levels in sea oats compared to other studies include a sampling protocol that did not focus on plants that were immediately adjacent to the $\mathrm{N}$ source (like the Ben- 
David et al. [1998a] river otter latrine study), the lower density of the $\mathrm{N}$ source (compared with islands whose soil is primarily guano [Anderson and Polis 1999]), the high leaching of the predominately sandy soil, and the dynamic nature of the high-energy beach environment. This environment may be more akin to the riparian environment found in the salmon studies (Ben-David et al. 1998b, Bartz and Naiman 2005), where affected plants also showed reduced levels of $\delta^{15} \mathrm{~N}$ enrichment.

Though not measured here, elevated $\mathrm{N}$ from the nests may generate community-level (Day et al. 2004) or structural effects in the dune vegetation, as shown with the salmon-borne nutrients (Bartz and Naiman 2005). $\delta^{15} \mathrm{~N}$ may move up trophic levels into sea oat arthropod communities (Rowan 1980, Hocking and Reimchen 2002), which may produce cascading effects through the recipient food web (Roth 2003). Moreover, such nutrient contributions to adjacent dune communities by sea turtles should be amplified in systems that experience arribadas (Bruemmer 1995), i.e., concentrated, mass nesting of Kemp's ridley (Lepidochelys kempi) and olive (L. olivacea) turtles, where nest densities can exceed 100000 nests/km (Shanker et al. 2004).

\section{AcKnowledgments}

We thank Tosha Dupras and Graham Worthy for access to the UCF Forensic Anthropology and Physiological Ecology and Bioenergetics Labs, respectively; Peter Weishampel and two anonymous reviewers for suggestions that greatly improved the manuscript; Jonathan Evans for related background information; and Victoria Albarracín, Matt Dyer, Michelle Wagner, and the UCF turtle crew, especially Kelly Roberts, Brian Thompson, Dean Bagley, and Karen Frutchey, for field and lab assistance. This project was funded, in part, by the Florida Federation of Garden Clubs and a UCF Biology Graduate Student Research Grant.

\section{Literature Cited}

Allaway, W. G., and A. E. Ashford. 1984. Nutrient input by seabirds to the forest on a coral island of the Great Barrier Reef. Marine Ecology Progress Series 19:297-298.

Anderson, W. B., and G. A. Polis. 1999. Nutrient fluxes from water to land: seabirds affect plant nutrient status on Gulf of California island. Oecologia 118:324-332.

Art, H. W., H. F. Bormann, G. K. Voigt, and G. M. Woodwell. 1974. Barrier island forest ecosystem: role of meteorological nutrient inputs. Science 184:60-62.

Bartz, K. K., and R. J. Naiman. 2005. Effects of salmon-borne nutrients on riparian soils and vegetation in southwest Alaska. Ecosystems 8:529-545.

Ben-David, M. T., R. T. Bowyer, L. K. Duffy, D. D. Roby, and D. M. Schell. 1998a. Social behavior and ecosystem processes: river otter latrines and nutrient dynamics of terrestrial vegetation. Ecology 79:2567-2571.

Ben-David, M., T. A. Hanley, and D. M. Schell. $1998 \mathrm{~b}$. Fertilization of terrestrial vegetation by spawning Pacific salmon: the role of flooding and predator activity. Oikos 83: $47-55$.

Bouchard, S. S., and K. A. Bjorndal. 2000. Sea turtles as biological transporters of nutrients and energy from marine to terrestrial ecosystems. Ecology 81:2305-2313.

Bruemmer, F. 1995. La arribada. Natural History 104:37-42.
Carthy, R. R., A. M. Foley, and Y. Matsuzawa. 2003. Incubation environment of loggerhead turtle nests: effects on hatchling success and hatchling characteristics. Pages 144 153 in A. B. Bolten and B. E. Witherington, editors. Loggerhead sea turtles. Smithsonian Institution, Washington, D.C., USA.

Dalton, D. A., S. Kramer, N. Azios, S. Fusaro, E. Cahill, and C. Kennedy. 2004. Endophytic nitrogen fixation in dune grasses (Ammophila arenaria and Elymus mollis) from Oregon. FEMS Microbiology Ecology 49:469-479.

Day, F. P. 1996. Effects of nitrogen availability on plant biomass along a barrier island dune chronosequence. Castanea 61:369-381.

Day, F. P., C. Conn, E. Crawford, and M. Stevenson. 2004. Long-term effects of nitrogen fertilization on plant community structure on a coastal barrier island dune chronosequence. Journal of Coastal Research 20:722-730.

Ehrhart, L. M., and P. W. Raymond. 1983. Loggerhead (Caretta caretta) and green turtle (Chelonia mydas) nesting densities on a major east central Florida USA nesting beach. American Zoologist 23:963.

Ellis, J. C., J. M. Fariña, and J. D. Witman. 2006. Nutrient transfer from sea to land: the case of gulls and cormorants in the Gulf of Maine. Journal of Animal Ecology 75:565-574.

Fariña, J. M., S. Salazar, K. P. Wallem, J. D. Witman, and J. C. Ellis. 2003. Nutrient exchanges between marine and terrestrial ecosystems: the case of the Galapagos sea lion Zalophus wollebaecki. Journal of Animal Ecology 72:873-887.

Godley, B. F., D. R. Thompson, S. Waldron, and R. W. Furness. 1998. Trophic status of marine turtles as determined by stable isotope analysis. Marine Ecology Progress Series 166:277-284.

Hayden, B. P., R. D. Dueser, J. T. Callahan, and H. H. Shugart. 1991. Long-term research at the Virginia Coast Reserve: modeling a highly dynamic environment. BioScience 41:310-318.

Heatwole, H. 1971. Marine dependent terrestrial biotic communities on some cays in the coral sea. Ecology 52: 363-366.

Hesp, P. A. 1991. Ecological processes and plant adaptations on coastal dunes. Journal of Arid Environments 21:165-191.

Hester, M. W., and I. A. Mendelssohn. 1989. Water relations and growth responses of Uniola paniculata (sea oats) to soil moisture and water-table depth. Oecologia 78:289-296.

Hester, M. W., and I. A. Mendelssohn. 1990. Effects of macronutrient and micronutrient additions on photosynthesis, growth parameters, and leaf nutrient concentrations of Uniola paniculata and Panicum amarum. Botanical Gazette 151:21-29.

Hocking, M. D., and T. E. Reimchen. 2002. Salmon-derived nitrogen in terrestrial invertebrates from coniferous forests of the Pacific Northwest. BMC Ecology 2:4.

Johnson, S. A. 1994. Reproductive ecology of the Florida green turtle (Chelonia mydas). Thesis. University of Central Florida, Orlando, Florida, USA.

Kachi, N., and T. Hirose. 1983. Limiting nutrients for plant growth in coastal sand dune soils. Journal of Ecology 71:937944.

Lajtha, K., and J. D. Marshall. 1994. Sources of variation in the stable isotope composition of plants. Pages $1-21$ in $\mathrm{K}$. Lajtha and R. H. Michener, editors. Stable isotopes in ecology and environmental science. Blackwell, Oxford, UK.

Lazell, J. D., and P. J. Auger. 1981. Predation on diamondback terrapin (Malaclemys terrapin) eggs by dunegrass (Ammophila breviligulata). Copeia 1981:723-724.

Miller, D. L., L. Yager, M. Thetford, and M. Schneider. 2003. Potential use of Uniola paniculata rhizome fragments for dune restoration. Restoration Ecology 11:359-369. 
Osegovic, K. M. 2001. Hatching success, embryonic mortality, and infertility in loggerhead (Caretta caretta) and green (Chelonia mydas) sea turtles nesting in Brevard County, Florida. Thesis. University of Central Florida, Orlando, Florida, USA.

Peterson, B. J., and B. Fry. 1987. Stable isotopes in ecosystem studies. Annual Review in Ecology and Systematics 18:293320.

Plog, L. B. 2004. Sea turtle nutrient inputs to dune vegetation: a stable isotope analysis. Thesis. University of Central Florida, Orlando, Florida, USA.

Roth, J. D. 2003. Variability in marine resources affects arctic fox population dynamics. Journal of Animal Ecology 72: 668-676.

Rowan, W. T. 1980. Insects found on sea oats, Uniola paniculata, in south Florida. Florida Scientist 63:341.

Sánchez-Piñero, F., and G. A. Polis. 2000. Bottom-up dynamics of allochthonous input: direct and indirect effects of seabirds on islands. Ecology 81:3117-3132.

Schoeninger, M. J., M. J. DeNiro, and H. Tauber. 1983. Stable nitrogen isotope ratios of bone collagen reflect marine and terrestrial components of prehistoric human diet. Science 220:1381-1383.

Shanker, K., B. Pandav, and B. C. Choudhury. 2004. An assessment of the olive ridley turtle (Lepidochelys olivacea) nesting population in Orissa, India. Biological Conservation 115:149-160.

Snyder, R. A., and C. I. Boss. 2002. Recovery and stability in barrier island plant communities. Journal of Coastal Research 18:530-536.

Stegmann, E. W., R. B. Primac, and G. S. Elimore. 1988. Absorption of nutrient exudates from terrapin eggs by roots of Ammophila breviligulata (Gramineae). Canadian Journal of Botany 66:714-718.
Stevenson, M. J., and F. P. Day. 1996. Fine-root biomass distribution and production along a barrier island chronosequence. American Midland Naturalist 135:205-217.

Sylvia, D. M. 1986. Spatial and temporal distribution of vesicular-arbuscular mycorrhizal fungi associated with Uniola paniculata in Florida foredunes. Mycologia 78:728-734.

Tabachnick, B. G., and L. S. Fidell. 2007. Using multivariate statistics. Pearson/Allyn and Bacon, Boston, Massachusetts, USA.

Turkowski, F. J. 1972. Grass sprout grows through embryo of yellow-bellied turtle (Chrysemys scripta). Herpetological Review 4:165.

van Berkum, P., and B. B. Bohlool. 1980. Evaluation of nitrogen fixation by bacteria in association with roots of tropical grasses. Microbiology Review 44:491-517.

Wagner, R. H. 1964. The ecology of Uniola paniculata L. in the dune-strand habitat of North Carolina. Ecological Monographs 34:79-96.

Weishampel, J. F., D. A. Bagley, and L. M. Ehrhart. 2004. Earlier nesting by loggerhead sea turtles following sea surface warming. Global Change Biology 10:1425-1428.

Weishampel, J. F., D. A. Bagley, and L. M. Ehrhart. 2006. Intra-annual loggerhead and green turtle spatial nesting patterns. Southeastern Naturalist 5:453-462.

Weishampel, J. F., D. A. Bagley, L. M. Ehrhart, and B. L. Rodenbeck. 2003. Spatiotemporal patterns of annual sea turtle nesting behaviors along an East Central Florida beach. Biological Conservation 110:295-303.

Witherington, B. E. 1986. Human and natural causes of marine turtle clutch and hatchling mortality and their relationship to hatchling production on an important Florida nesting beach. M.S. Thesis. University of Central Florida, Orlando, Florida, USA. 